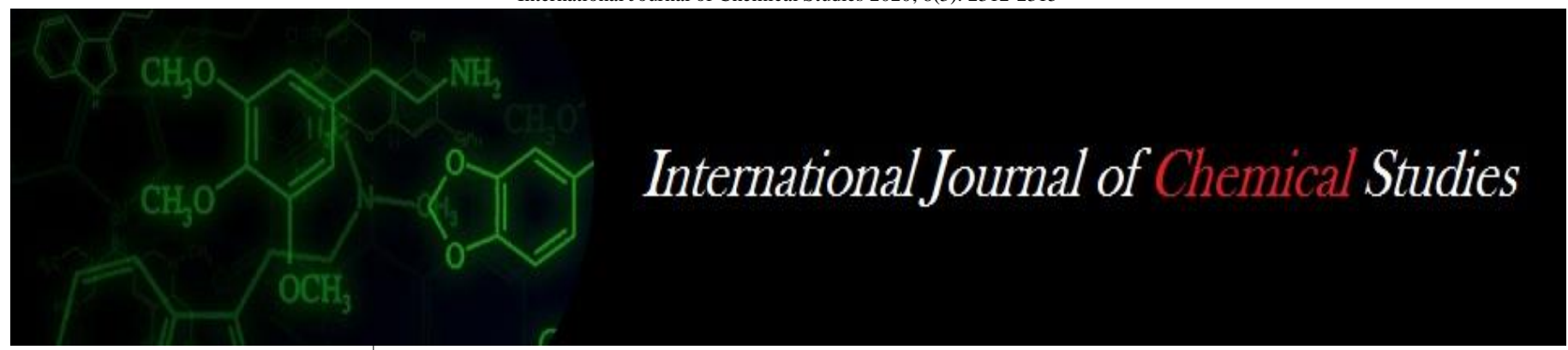

P-ISSN: 2349-8528

E-ISSN: 2321-4902

www.chemijournal.com

IJCS 2020; 8(3): 2312-2315

(C) 2020 IJCS

Received: 15-03-2020

Accepted: 20-04-2020

\section{Rahul Chaudhary}

Department of Agricultural

Botany, R.M.P. (P.G.) College,

Gurukul Narsan Haridwar,

Uttarakhand, India

\section{Shiv Kumar}

Department of Agricultural

Botany, R.M.P. (P.G.) College,

Gurukul Narsan Haridwar,

Uttarakhand, India

Sarvendra Singh

Department of Agricultural

Entomology, R.M.P. (P.G.)

College, Gurukul Narsan

Haridwar, Uttarakhand, India

Janeshwar Prasad

Department of Agricultural

Botany, R.M.P. (P.G.) College,

Gurukul Narsan Haridwar,

Uttarakhand, India

\section{AS Jeena}

Department of Genetics and

Plant Breeding, G B Pant

University of Agriculture and

Technology, Pantnagar,

Uttarakhand, India

\section{Upreti}

Department of Genetics and

Plant Breeding, G B Pant

University of Agriculture and

Technology, Pantnagar,

Uttarakhand, India
Corresponding Author: Rahul Chaudhary

Department of Agricultural Botany, R.M.P. (P.G.) College,

Gurukul Narsan Haridwar,

Uttarakhand, India

\section{Study of genetic parameters and character association in wheat (Triticum aestivum $\mathrm{L}$.)}

\author{
Rahul Chaudhary, Shiv Kumar, Sarvendra Singh, Janeshwar Prasad, AS \\ Jeena and MC Upreti
}

DOI: https://doi.org/10.22271/chemi.2020.v8.i3ag.9555

\begin{abstract}
The present investigation was carried out with an objective of assessing the genetic variability, heritability and genetic advance for thirteen quantitative characters and interrelationship among them. Thirty-six wheat genotypes were evaluated in RBD with three replications. The ANOVA revealed highly significant variation among the genotypes, indicating the presence of ample amount of variability which can be exploited for selection of characters for crop improvement programme. GCV was observed highest in case of days to emergence followed by biological yield and awn length. Characters with high estimates of variance like plant height, number of grains per spike, harvest index and biological yield can be considered in selection for improvement of the crop species. Heritability in broad sense was observed highest for hundred grain weight followed by days to emergence and length of spike, whereas, genetic Advance as a percent of mean was found maximum in case of days to emergence followed by biological yield and awn length. Grain yield showed highly significant positive correlation with biological yield and significant positive correlation with harvest index however it showed significant and negative corr. with tillers per plant. On the basis of study, the most promising donors for grain yield were found viz., WP710/17, TALL-2, WP705/17 and WP708/17. These genotypes can be used for further breeding programme to improve the yield potential of the variety.
\end{abstract}

Keywords: Wheat, Triticum aestivum, variability, correlation, yield components

\section{Introduction}

Wheat (Triticum aestivum L.) is the world's largest cereal crop. It occupies, high productivity and the prominent position in the international food grain trade. It is an important staple food of many countries in the world and occupies a unique position as used for the preparation of a wide range of food stuffs. India is one of the major producers of wheat and ranks second after China in area and production. In India the total production of wheat has increased from $12.6 \mathrm{~m}$ tones (1965-66) to about $98.61 \mathrm{~m}$ tones, area $29.72 \mathrm{~m}$. hectare and productivity 33.18 during 2017-18. In Uttarakhand the total wheat area was 33 thousand-hectare, total production 880 thousand tonne and productivity was 26.43 qt. per hectare during Rabi 2017-18. (Anonymous, 2018). The development of high yielding wheat cultivars is the main objective of any wheat breeding programmes in the world. Identification of better genotypes with desirable traits and their subsequent use in breeding programme and establishment of suitable selection criterion can helpful for successful varietals improvement programme. Analysis of variability among the traits and the association of a particular character in relation to other traits contributing to yield of a crop would be of great importance in planning a successful breeding program. Genetic Variability is an absolute necessity for survival of a species. It facilitates genotypes with ability to adapt according to the conditions prevailing. The extent of genetic variability is considered as an important factor and a must pre-requisite for a successful hybridization programme (Nakusani et al. 2013) ${ }^{[14]}$. Genetic variability is a sure thing which is required for any crop improvement programme to succeed. Kumar et al. $(2013){ }^{[8,9,10]}$ reported moderate GCV and PCV values for biological yield per plant and number of effective tillers per plant. Patel et al. (2015) suggested an ideal plant type in wheat would be one with like number of tillers per plant, number of spikelets per spike, and days to maturity, 1000-seed weight, biological yield and harvest index. 
Heritability on the other hand is a parameter widely used in establishment of breeding programs and formation of selection indices (Falconer, 1985) ${ }^{[6]}$ as it gives an idea about the transmissibility of the trait of interest. As it is difficult to select suitable parents for poly genetically controlled characters, therefore, for efficient selection of superior parents there's a need of adequate genetic variation as well as considerable heritability of the trait of interest. Heritability is further divided into broad sense and narrow sense. Broad sense heritability is defined as the ratio of genotypic variance to phenotypic variance, whereas narrow sense heritability is the ratio of additive variance to total or phenotypic variance and both are expressed in percentage. Heritability along with genetic advance helps in assessing the amount of improvement that can be achieved through selection and gives an idea about which type of crop improvement methodology would work. Rajput (2018) ${ }^{[16]}$ reported high heritability and genetic advance for canopy temperature index and harvest index. Therefore, development of high-yielding varieties requires through knowledge of the existing genetic variation for yield and its components. In this regard, it is necessary to survey the available useful variability and nature of association among the various plant characters in the basic material. The correlation coefficient gives an idea about the various associations existing between the yield components. Therefore, the present investigation had been conducted to estimate the extent of variability, heritability and genetic advance for yield and its components and to assess the nature and magnitude of inter-character correlation among different characters in wheat germplasm lines.

\section{Materials and Methods}

The present study was conducted at Research farm of R.M.P. P.G. College, Gurukul Narsan, Haridwar (Uttarakhand) with 36 improved genotype of bread wheat. The Gurukul Narsan is situated in the foothills of Shivalik range of Himalaya and falls in the humid sub-tropical climate Zone. The Material was planted in a randomized complete block design with three replications under timely sown Condition in the plot consists of 2 row of $2.5 \mathrm{~m}$ length spaced at $23 \mathrm{~cm}$. the observations were recorded on a random sample of 10 plants from each plot for 13 quantitative characters viz., Days to emergence, Plant height $(\mathrm{cm})$, No of tillers/plant, Spike length $(\mathrm{cm})$, Awn length $(\mathrm{cm})$, No. of spikelet /spike, No. of grains/spikelet, No. of grains/ spike, Grain weight/ear (gm), 100 grain weight (gm), Biological yield (gm), Harvest Index and Grain yield/plant (gm).

Genetic parameters viz., Mean, Range, Coefficients of variability (PCV and GCV) along with heritability in broad sense, genetic advance and genetic advance as percent of mean and correlation coefficient were estimated for the character studied. Analysis of variance permits estimation of phenotypic, genotypic and environmental coefficients of variability. When coefficient of variability is high the sample is less consistent or more variable and when it is low the sample is more consistent and less variable. Estimation of different coefficients of variability was done following Burton (1953) ${ }^{[4]}$. Heritability in broad sense was calculated for each character as described by Johnson et al. (1955) ${ }^{[7]}$ while the expected genetic advance from straight selection as per Allard (1960) ${ }^{[2]}$. Correlation coefficients between all possible pairs of characters were calculated at genotypic and phenotypic level. The analysis of variance and covariance was used for the estimation of correlation coefficient as suggested by Searle, $1961^{[17]}$.

\section{Results and Discussion}

The genetic variation is the source which is exploited to improve a species and as result new efficient cultivars are achieved. In populations genetic drift is a constant phenomenon due to which species gradually loose genetic Variation. This loss of variability hampers the potential of the species and therefore, there's a need for its conservation and determination as well. The results of ANOVA revealed that the mean sum of squares among the genotypes for all the characters were highly significant, which indicated that the genotypes were genetically divergent. This implicated that there is a great scope of selection of promising genotypes from the present gene pool. Information on the extent of genetic variability as well as heritability among the agronomically important traits is the requirement to design a suitable plant breeding method (Abinasa et al, 2011) ${ }^{[1]}$. It's very important for a plant breeder to have knowledge of genetic variability and the amount of heritable variation for important traits. Sometimes the trait of interest is influenced by the environmental conditions prevailing, especially in case of polygenic characters so it becomes important to partition the total variability components, to have information regarding the nature and extent of actual variability present. Range, General Mean (GM), GCV, PCV \& ECV, broad sense heritability $\left(\mathrm{h}^{2} \mathrm{~b}\right)$ and genetic advance as percent of mean were estimated and are presented in Table 1

As per the Table 1, it was found that the PCV and GCV values were high for most of the characters taken into consideration except for Number of Spikelet per spike, and 100 grain weight, whereas, length of spike, number of grains per spikelet, number of grains per spike and grain weight per ear showed moderate PCV \& GCV which indicated that the genotypes had a considerable amount of variability. The value of phenotypic coefficient of variation (PCV) was found to be highest for awn length (30.026\%), followed by days to emergence $(29.724 \%)$ and biological yield $(28.876 \%)$ and was lowest for number of spikelets per spike $(8.552 \%)$. In case of genotypic coefficient of variation (GCV) the highest value was recorded for days to emergence (29.370\%), followed by biological yield $(27.808 \%)$ and awn length $(27.618 \%)$ and the lowest value was recorded for number of spikelets per spike $(7.571 \%)$. The values of PCV and GCV are found lowest in case of number of spikelets per spike indicating presence of less variation for the trait. Similar findings were also reported by Kumar et al (2008) ${ }^{[12,13]}$ and Kumar et al (2013) ${ }^{[8,9,10]}$.

Heritability in broad sense (h2b) was recorded maximum for hundred grain weight $(99.6 \%)$, followed by days to emergence $(97.6 \%)$ and length of spike $(95.6 \%)$, whereas, was minimum for number of grains per spikelet $(40.3 \%)$. The value of genetic advance as percent of mean was observed highest for days to emergence $(59.781 \%)$, followed by biological yield $(55.165 \%)$ and awn length $(52.334 \%)$ and lowest for number of grains per spikelet $(11.046 \%)$. Moderate to high heritability was observed for all the characters with low to moderate genetic advance which indicated the role of non-additive genes. In such condition simple selection methods will not work and will give limited improvement, therefore, some kind of inter- and intra-population improvement practices will result in accumulation of favourable genes for a long period. Low heritability with low genetic advance was observed in case of number of grains per spikelet which indicated the inefficiency of simple selection procedures for the trait concerned. Similar findings were also 
reported by Chavda et al (2013) ${ }^{[5]}$ and Kumar et al (2013) ${ }^{[8,}$ $9,10]$

Genetic architecture of yield can be better resolved through component rather than yield per se, as the yield is the end product of multiplicative interaction between the various yield components. Earlier workers had emphasized significance of components approach in forming a successful breeding programmed. The correlation coefficient gives an idea about the various associations existing between yield and yield contributing components. Grain yield is a complex character resulting from multiplicative interaction of yield components and therefore. Selection for the character becomes very difficult task. So, knowledge of relationship between grain yield and its various comports in necessary. The correlation coefficients among different characters have been presented in Table 2.

Grain yield showed highly significant positive correlation with biological yield and significant positive correlation with harvest index however it showed significant and negative association with tillers per plant. Harvest index exhibited highly significant positive correlation with tillers per plant and significant positive correlation with biological yield.
Similar relationships were recorded by Kumar et al. (2014) ${ }^{[11]}$. Biological yield showed highly significant positive correlation with plant height and number of spikelets per spike. Similar observations were also reported Tsegaye et al. (2012) ${ }^{[18]}$. 100 grain weight showed highly significant positive correlation with awn length and number of spikelets per spike while it showed significant positive correlation with grains per ear. Grain weight per ear exhibited highly significant and positive correlation with number of grains per spike, number of spikelets per spike and awn length. Number of grains per spike showed highly significant correlation with number of spikelets per spike. Number of grains per spikelet showed significant and positive correlation with tiller per plant and number of spikelets per spike. Number of spikelets per spike exhibited highly significant and positive correlation with spike length tiller. Tillers per plant showed significant and positive correlation with plant height. Spike length showed highly positive significant and positive correlation with plant height. Tiller per plant showed significant and positive correlation with plant height. Similar results were obtained by Kumar et al $2008^{[12,13]}$ and Vikas et al (2013) ${ }^{[8,}$ 19].

Table 1: Mean, Range, Phenotypic (PCV) and Genotypic (GCV) Coefficients of Variation, Heritability (h ${ }^{2}$ ) , Genetic advance (GA) and Genetic advance as $\%$ of mean (GAM) for yield and its components in wheat

\begin{tabular}{|c|c|c|c|c|c|c|c|c|}
\hline Character & Mean & Range & PCV & GCV & ECV & $\mathbf{h}^{2}{ }_{b}$ & GA & GAM \\
\hline Days to emergence & 12.954 & $7.000-16.333$ & 29.724 & 29.370 & 4.571 & 0.976 & 7.744 & 59.781 \\
\hline Plant height $(\mathrm{cm})$ & 88.958 & $74.567-98.867$ & 20.035 & 17.905 & 8.989 & 0.799 & 29.323 & 32.963 \\
\hline Number of tillers per plant & 6.463 & $4.333-8.667$ & 22.692 & 18.016 & 13.796 & 0.631 & 1.904 & 29.460 \\
\hline Length of spike $(\mathrm{cm})$ & 10.008 & $8.067-11.833$ & 11.237 & 10.987 & 2.356 & 0.956 & 2.215 & 22.132 \\
\hline Awn length $(\mathrm{cm})$ & 7.028 & $4.700-8.833$ & 30.026 & 27.618 & 11.782 & 0.846 & 3.678 & 52.334 \\
\hline Number of spikelets per spike & 19.870 & $17.333-22.667$ & 8.552 & 7.571 & 3.976 & 0.784 & 2.744 & 13.809 \\
\hline Number of grains per spikelet & 3.241 & $3.000-4.000$ & 13.298 & 8.443 & 10.273 & 0.403 & 0.358 & 11.046 \\
\hline Number of grains per spike & 59.927 & $43.333-82.000$ & 16.748 & 15.262 & 6.897 & 0.830 & 17.166 & 28.649 \\
\hline Grain weight per ear (gm) & 2.676 & $2.010-4.007$ & 18.894 & 14.719 & 11.845 & 0.607 & 0.632 & 23.617 \\
\hline 100 grain weight $(\mathrm{gm})$ & 4.343 & $3.483-5.667$ & 10.456 & 10.435 & 0.655 & 0.996 & 0.932 & 21.459 \\
\hline Biological yield $(\mathrm{gm})$ & 30.773 & $19.333-65.200$ & 28.876 & 27.808 & 7.782 & 0.927 & 16.976 & 55.165 \\
\hline Harvest index $(\%)$ & 49.362 & $19.937-74.667$ & 25.373 & 21.964 & 12.704 & 0.749 & 19.333 & 39.166 \\
\hline Grain yield per plant (gm) & 14.550 & $9.000-21.263$ & 22.664 & 19.855 & 10.929 & 0.767 & 5.214 & 35.835 \\
\hline
\end{tabular}

Table 2: Genotypic (G), Phenotypic (P) and Environmental (E) Correlation coefficients exhibiting interrelationship among yield and different yield components in wheat.

\begin{tabular}{|c|c|c|c|c|c|c|c|c|c|c|c|c|c|}
\hline Characters & & $\begin{array}{l}\text { Plant } \\
\text { height }\end{array}$ & $\begin{array}{l}\text { Tillers } \\
\text { per } \\
\text { plant }\end{array}$ & $\begin{array}{c}\text { Spike } \\
\text { length }\end{array}$ & $\begin{array}{c}\text { Awn } \\
\text { length }\end{array}$ & $\begin{array}{c}\text { No. of } \\
\text { spikelet } \\
\text { per spike }\end{array}$ & $\begin{array}{c}\text { No. of } \\
\text { grains per } \\
\text { spikelet } \\
\end{array}$ & \begin{tabular}{|c|}
$\begin{array}{c}\text { No of } \\
\text { grains per } \\
\text { spike }\end{array}$ \\
\end{tabular} & \begin{tabular}{|c|} 
Grain \\
weight per \\
ear
\end{tabular} & $\begin{array}{c}100 \text { grain } \\
\text { weight }\end{array}$ & $\begin{array}{c}\text { Biological } \\
\text { yield }\end{array}$ & $\begin{array}{c}\text { Harvest } \\
\text { Index }\end{array}$ & $\begin{array}{c}\text { Grain } \\
\text { yield per } \\
\text { plant }\end{array}$ \\
\hline \multirow{3}{*}{$\begin{array}{l}\text { Days to } \\
\text { emergence }\end{array}$} & $\mathrm{G}$ & 0.127 & 0.170 & 0.014 & 0.244 & 0.077 & 0.121 & -0.150 & -0.049 & 0.139 & 0.008 & 0.175 & 0.095 \\
\hline & $|\mathrm{P}|$ & 0.124 & 0.130 & 0.013 & 0.206 & 0.081 & 0.076 & -0.120 & -0.040 & 0.139 & 0.006 & 0.150 & 0.078 \\
\hline & $\mathrm{E}$ & 0.165 & -0.035 & -0.039 & -0.259 & 0.189 & -0.001 & 0.236 & -0.025 & 0.201 & -0.022 & -0.814 & -0.035 \\
\hline \multirow{3}{*}{ Plant height } & $\mathrm{G}$ & & $0.359^{*}$ & $0.429 * *$ & 0.116 & $0.409 *$ & 0.153 & 0.197 & 0.112 & -0.251 & $0.366^{*}$ & 0.276 & -0.272 \\
\hline & $\mathrm{P}$ & & 0.238 & $0.365^{*}$ & -0.105 & 0.313 & 0.141 & 0.204 & 0.147 & -0.223 & 0.320 & 0.208 & -0.225 \\
\hline & $\mathrm{E}$ & & -0.063 & -0.110 & -0.054 & -0.054 & 0.157 & 0.236 & 0.244 & 0.024 & 0.044 & -0.036 & -0.068 \\
\hline \multirow{3}{*}{$\begin{array}{l}\text { Tillers per } \\
\text { plant }\end{array}$} & $\mathrm{G}$ & & & -0.125 & -0.182 & 0.130 & $0.381 *$ & -0.196 & -0.281 & -0.281 & $0.607 * *$ & $0.492 * *$ & $-0.355^{*}$ \\
\hline & $\mathrm{P}$ & & & -0.094 & -0.154 & 0.044 & 0.201 & -0.124 & -0.154 & -0.221 & $0.522 * *$ & $0.432 * *$ & -0.225 \\
\hline & $\mathrm{E}$ & & & 0.020 & -0.087 & -0.017 & 0.019 & 0.068 & 0.054 & 0.062 & 0.351 & 0.304 & 0.061 \\
\hline \multirow{3}{*}{ Spike length } & $\mathrm{G}$ & & & & -0.272 & $0.468 *$ & 0.110 & 0.251 & 0.113 & -0.226 & 0.075 & -0.122 & -0.307 \\
\hline & $\mathrm{P}$ & & & & -0.226 & 0.414 & 0.056 & 0.216 & 0.074 & -0.219 & 0.077 & -0.097 & -0.261 \\
\hline & $\mathrm{E}$ & & & & 0.235 & 0.098 & -0.076 & -0.085 & -0.086 & 0.112 & 0.121 & 0.073 & -0.013 \\
\hline \multirow{3}{*}{ Awn length } & $\mathrm{G}$ & & & & & 0.055 & 0.198 & 0.247 & $0.594 * *$ & $0.438 * *$ & -0.089 & 0.046 & 0.191 \\
\hline & $\mathrm{P}$ & & & & & 0.054 & 0.171 & 0.211 & $0.414 * *$ & 0.402 & -0.081 & 0.005 & 0.134 \\
\hline & $\mathrm{E}$ & & & & & 0.047 & 0.182 & 0.022 & -0.047 & -0.008 & -0.019 & -0.167 & -0.091 \\
\hline \multirow{3}{*}{$\begin{array}{c}\text { No. of spikelet } \\
\text { per spike }\end{array}$} & $G$ & & & & & & $0.409 *$ & $0.534 * *$ & $0.536^{* *}$ & $0.470 * *$ & $0.364^{*}$ & 0.175 & -0.224 \\
\hline & $\mathrm{P}$ & & & & & & 0.244 & $0.480 * *$ & $0.423 * *$ & $0.438 * *$ & 0.308 & 0.172 & -0.125 \\
\hline & $\mathrm{E}$ & & & & & & & 0.260 & 0.183 & 0.081 & -0.014 & 0.163 & 0.198 \\
\hline \multirow{3}{*}{\multicolumn{2}{|c|}{\begin{tabular}{c|c} 
No. of grains \\
per spikelet
\end{tabular}}} & & & & & & & 0.227 & 0.212 & -0.182 & 0.270 & 0.159 & -0.192 \\
\hline & & & & & & & & 0.241 & 0.213 & -0.110 & 0.143 & 0.068 & -0.077 \\
\hline & & & & & & & & $0.344 *$ & 0.223 & 0.115 & -0.108 & -0.054 & 0.074 \\
\hline No of grains & $\mathrm{G}$ & & & & & & & & $0.864 * *$ & -0.089 & 0.152 & 0.135 & 0.124 \\
\hline
\end{tabular}




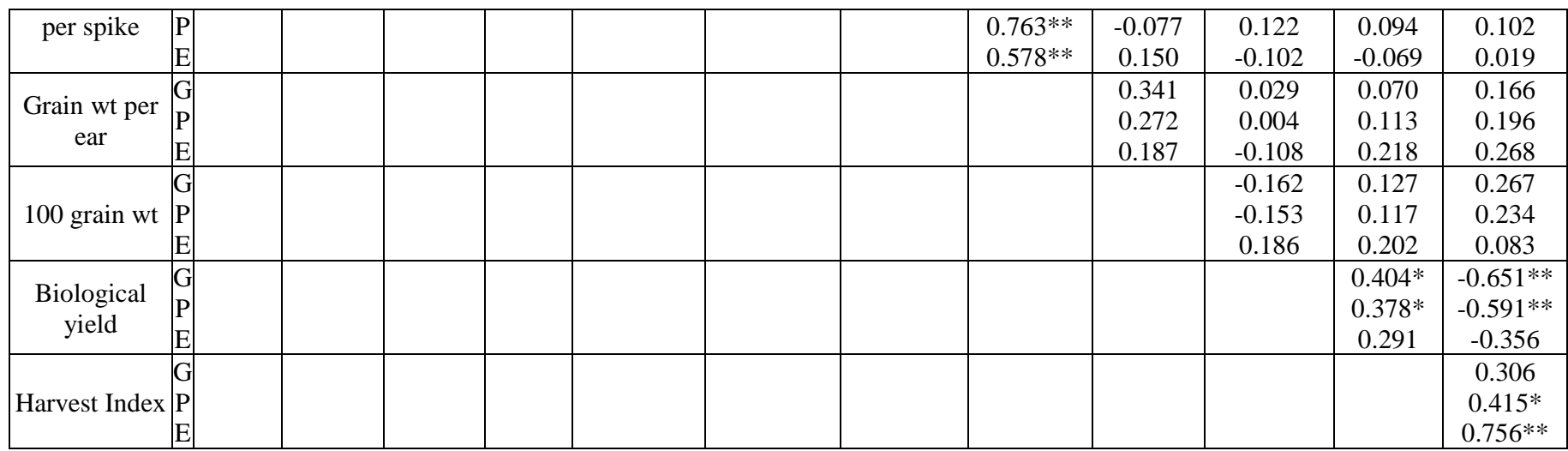

\section{Conclusion}

The present investigation revealed ample amount of variability among wheat germplasm which can be exploited for selection of characters for crop improvement programme. Characters with high estimates of variance like plant height, number of grains per spike harvest index, and biological yield can be considered in selection for improvement of the crop species. Low heritability with low genetic advance was recorded for grains per spikelet, which indicated difficulty in improvement of the trait by simple selection. Heritability along with genetic advance becomes more useful tool for the prediction of the method of improvement to be applied, rather than heritability alone. As per results heritability in broad sense was ranging from high to moderate, whereas genetic advance as a percent of mean was ranging from moderate to low, which signified the ineffectiveness of simple selection measures for the improvement of genotypes. Use of inter- and intra-population improvement methods will be more beneficial. On the basis of study, the desirable donors for each character were identified. The most promising donors for grain yield were WP710/17, TALL-2, WP705/17 and WP708/17. These genotypes can be used for further breeding programme to improve the yield potential of the variety.

\section{References}

1. Abinasa M, Ayana A, Bultosa G. Genetic variability, heritability and trait associations in durum wheat (Triticum turgidum L. var. durum) genotypes. African Journal of Agricultural Research. 2011; 6(17):3972-3979.

2. Allard RW. Principles of Plant Breeding. John Wiley and Sons, 1960.

3. Anonymous. Progress report of All India Coordinated Wheat and Barley Improvement 2018, Director's report of AICRP on Wheat and Barlay 2017-18. Ed. G.P. Singh, Indian Institute of Wheat and Barley Research, Kernal, India, 2018, 94.

4. Burton GW. Quantitative inheritance in grasses. Proc. Int. Grassland Congr. 1953; 1:277-283.

5. Chavda VS, Kumar S, Jeena AS, Kumar A, Dhama SK, Prasad $\mathrm{J}$ et al. Genetic variability and response to selection in bread wheat (Triticum aestivum L. Em., Thell.). Progressive Research. 2013; 8(Special):263-266

6. Falconer DS. Introduction to Quantitative Genetics. Longman Inc. London and Newyork, 1985.

7. Johnson HW, Robinson HF, Comstock RE. Estimates of genetic and environmental variability in soybeans. Agronomy Journal. 1955; 47(7):314-318.

8. Kumar A, Vikas, Kumar S, Jeena AS, Upreti MC, Kushwah PS. Genetic variability, heritability and genetic advance in bread wheat (Triticum aestivum L. Em., Thell.). Progressive Research. 2013; 8(Special):273-275
9. Kumar A, Kumar S, Dhama SK, Jeena AS, Chavda VS, Kumar B. Studies on genetic variability in bread wheat (Triticum aestivum L. Em., Thell.). Progressive Research. 2013; 8(Special):281-285.8448121376

10. Kumar B, Singh CM, Jaiswal KK. Genetic variability, Association and Diversity Studies in Bread Wheat (Triticum aestivum L.). The Bioscan. 2013; 8(1):143-147.

11. Kumar R, Bhushan B, Pal R, Gaurav SS. Correlation and path coefficient analysis for quantitative traits in wheat (Triticum aestivum L.) under normal condition. Annals of Agri-Bio Research. 2014; 19(3):447-450.

12. Kumar S, Malik SS, Jeena AS, Malik SK. Pattern of genetic parameters in early generation selection in wheat (Triticum aestivum L.). Int. J Plant Sci. 2008; 3(2):613616

13. Kumar S, Malik SS, Jeena AS, Malik SK. Interrelationship among the yield attributes and intergeneration Correlation as a mean of testing effectiveness of early generation testing in wheat (T. aestivum L.). Progressive Research. 2008; 3(1):25-30

14. Nukasani V, Potdukhe NR, Bharad S, Deshmukh S, Shinde SM. Genetic variability, correlation and path analysis in wheat. Journal of Wheat Research. 2013; 5(2):48-51.

15. Patel DD, Moitra PK, Shukla RS. Genetic variability, correlation and path coefficient analysis in wheat (Triticum aestivum L.). Frontiers in crop improvement journal. 2015; 3(1):25-28.

16. Rajput RS. Correlation, path analysis, heritability and genetic advance for morpho-physiological character on bread wheat (Triticum aestivum L.). Journal of Pharmacognosy and Phytochemistry. 2018; 7(2):107-112.

17. Searle SR. Phenotypic, genotypic and environmental correlations. Biometrica. 1961; 17:475-480.

18. Tsegaye D, Dessalegn T, Dessalegn Y, Share G. Genetic variability, correlation and path analysis in durum wheat germplasm (Triticum durum Desf). Agricultural Research and Reviews. 2012; 1(4):107-112.

19. Vikas, Kumar A, Kumar S, Jeena AS, Prasad J, Upreti MC. Genetic variability and character association in bread wheat (Triticum aestivum L. Em., Thell.). Progressive Research. 2013; 8(Special):289-291 